"Problem Children" and "Children with Problems":

Discipline and Innocence in a Gentrifying Elementary School

\title{
ALEXANDRA FREIDUS
}

Seton Hall University

This article examines the ways Hazel, a white girl entering kindergarten, became known as a child with a problem rather than a problem child in her gentrifying school. Building on a year of classroom observations and interviews with students, school staff, and parents, author Alexandra Freidus identifies the role of racialized discourses related to disposition, medicalization, and family and community in shaping Hazel's reputation and contrasts Hazel's reputation with that of Marquise, a Black boy in her class. Hazel's and Marquise's storylines teach us that to fully understand and address the differences in how Black and white children are disciplined, we need to look closely at the allowances and affordances we make for some students, as well as how we disproportionately punish others. By examining the ways educators in a gentrifying school construct white innocence and Black culpability, this study illustrates the relational nature of the "school discipline gap" and helps us understand how and why some children are disproportionately subject to surveillance and exclusion when others are not.

NOTE: This article preprint has not yet been copyedited and may differ slightly from the final published version, which is forthcoming in Harvard Educational Review, 90(4). 
As decades of research has shown, it is exceedingly difficult for some students, most frequently Black boys, to be seen as "good” (Ferguson, 2000; Gilliam, Maupin, Reyes, Accavitti, \& Shic, 2016; Skiba, Michael, Carroll Nardo, \& Peterson, 2000). More recently, research has also demonstrated that for other students, most frequently white girls, it is exceedingly difficult to be seen as "bad” (Diamond \& Lewis, 2016; Morris, 2005a; Musto, 2019). ${ }^{1 \mathrm{i}}$ In this study of a kindergarten student and her classroom, ,I look closely at Hazel, a white girl in a gentrifying elementary school in New York City, toidentify the roles that the discursive frames of disposition, medicalization, and family and community play in shaping racialized reputations of white innocence and Black culpability (MacLure, Jones, Holmes, \& Macrae, 2012). ${ }^{2}$ I argue that as educators and researchers seek to better understand and address the racialized discipline gap, we must understand not only how and why some kids are disproportionately subjected to exclusionary school discipline but also how and why others are not. In doing so, I examine the relational nature of discipline practices that criminalize some students and medicalize others who are deemed to be misbehaving (Ferguson, 2000; Ramey, 2015; Shalaby, 2017).

In a classroom of 17 children, Hazel stood out. She was 1 of 2 white kids in her class, 4 in her grade, and 18 in her school of more than 300 students. She was the only white girl in kindergarten that year. Unlike many of her peers, who lived in a decades-old public housing project, Hazel lived with her family in a new luxury apartment building. Her parents, an adjunct art professor and a freelance writer, qualified for reduced rent in the development under New York's affordable housing policy. Both Hazel's family and the school staff frequently noted the literal and figurative distances between Hazel's home, eight blocks away, and those of her peers in public housing just down the street. 
Hazel wore her blonde hair in a ponytail with a cowlick that frequently stood up, almost vertically, from the top of her head. She was slim and slightly shorter than many of her classmates. Her voice was soft and squeaky. When she cried at school—which happened frequently—she generally did so quietly, disrupting the class as little as possible. Both adults and children at her school enjoyed talking with Hazel, but they were troubled by some of her behaviors. Each morning at drop-off, Hazel clung to her mother or father and refused to enter the classroom. One day about three weeks into the school year, her refusal at the classroom doorway escalated into rebellion. As her mother stood by helplessly, Hazel screamed and howled and kicked, and then Hazel tried to bite her teacher. After a few minutes of anguished indecision, her mother took her home. Nobody spoke to Hazel about what had happened when she returned to school the next day.

In this article, I explore why Hazel's school did not discipline her, despite her breach of school and classroom norms. I illustrate how Hazel acquired a reputation for being a child with a problem rather than a problem child - in her gentrifying school.. Building on a year of classroom observations and interviews, I examine how racialized discourses of disposition, medicalization, and family and community influenced how adults and kids alike interpreted Hazel's behavior (MacLure et al., 2012). I then contrast Hazel's reputation with the counternarrative of Marquise, a Black boy who was her classmate.

It appeared to me that both children's behaviors were expressions of difficulty with their transitions to kindergarten. However, the conclusions that educators in the school drew about each child were quite different. The stakes for these children's evolving reputations were quite high; they contributed to significantly divergent outcomes for Hazel and Marquise. As a participant-observer, I was struck by moments in which Marquise was not offered "the same 
grace, empathy, and humanization as White children" in response to "problematic" behavior (Halberstadt et al., 2020, p. 11). Yet, rather than considering how "problem children" like Marquise are marked as troublemakers, I look at how children like Hazel are marked as "good." Here, I examine the role race and gender played in ensuring that Hazel received therapy while Marquise was punished for his behavior. I argue that the resulting "school discipline gap" (Gregory, Skiba, \& Noguera, 2010) is not only racialized; itis one symptom of a relational system in which children are marked by "goodness"- as well as by race and gender-relative to each other (Broderick \& Leonardo, 2016). Racial storylines (Nasir, Snyder, Shah, \& Ross, 2013) about who Black children are and who they can be, relative to white children, inform how we perceive and respond to student behaviors, simultaneously producing both Black culpability and white innocence.

\section{The Problem of Reputation}

Maclure et al. (2012) contend that "reputation is a public matter; a child becomes a problem in the eyes of others" (p. 448). While children's actions and interactions contribute to their reputations, they do so according to a circular logic: their behaviors are read “metonymically, as ‘standing for' a bigger problem” (p. 455). Reputations harden relatively quickly and become deeply entrenched over the course of the academic year so that children's behaviors simultaneously are read through and reinscribe these frames (Wortham, 2008). Adults and kids are quick to use terms such as good, troublemaker, or tomboy to make sense of interactions among children, between children and adults, and between children and the curriculum (Musto, 2019; Shalaby, 2017; Thorne, 1993; Wortham, 2006). These labels, which 
may appear to be neutral descriptions of behavior, implicitly index race and gender (Broderick \& Leonardo, 2016).

Reputations are solidified through the use of classroom artifacts (e.g., rewards charts), public praise and condemnation, and the selective enforcement of rules and consequences (Hatt, 2012; Jackson, 1968; Wortham, 2006). As Broderick and Leonardo (2016) argue, once established, labels, both positive and negative, are "nearly impossible to undo" (p. 58). Maclure et al. (2012) found that adults regularly interpret young children's behavior through three discursive frames: disposition, medicalization, and family and community. Discourses of disposition, or the underlying attributes of the child herself, most frequently take the form of judgments about an individual's character. The circular logic of reputation operates such that a discrete act is read as a sign of a child's disposition, her essential nature; at the same time, her reputation makes it more likely that the child's actions will be read that way again in the future. Medicalization discourses frame children's behavior through the diagnostic lenses of physical or psychological conditions, such as Attention Deficit Hyperactivity Disorder (ADHD), and may become further hardened through bureaucratic technologies such as Individualized Educational Plans (Mehan, 1996). Family and community discourses, in contrast, consist of "narratives of the neglectful, indulgent, anxious, uncooperative or interfering parent” (MacLure et al., 2012, p. 454), leading to the conclusion that it is the family or the community, rather than the child, that bears responsibility for behavioral challenges.

Here I investigate how norms of goodness, whiteness, and childhood intersect with the ways children do or do not acquire reputations as "problem children.” I ask why Hazel's behavior, which frequently disrupted classroom activities and norms, was seen as very different from that of Marquise. In doing so, I interrogate the role of race and gender in Maclure et al.'s 
(2012) framework. I examine the ways that whiteness and femininity shape perceptions of innocence and culpability to explain how Hazel did not, as Maclure et al. might have predicted, "become a problem" in her classroom and her school. Building on a substantial body of research that details the ways Black boys are seen as "bad" (Ferguson, 2000; Goff, Jackson, Di Leone, Culotta, \& DiTomasso, 2014; Noguera, 2008), I explore the inverse: the logics and discourses that presume white girls are "good."

\section{Race, Gender, and the Good Child}

As many of us who have experienced formal schooling are well aware, "good" children are quiet. They follow the behavioral norms of sitting still and following directions, conforming to classroom rules, and accepting adult authority that constitute the core hidden curriculum of schooling (Jackson, 1968; Shalaby, 2017). They successfully negotiate conflicting expectations of competition and sharing, participation and quietness, independence and compliance at the heart of most early childhood classrooms (Hatt, 2012; MacLure et al., 2012; Mehan, 1980). What is more, they are seen to be doing so. They may not always listen perfectly, but they are recognized as good listeners (Broderick \& Leonardo, 2016; Wortham, 2006).

Public recognition is central to an ideology in which a good child passes through orderly, normalized stages of development (MacLure et al., 2012; Walkerdine, 1998). This ideological system is not race neutral: the normative child is white. Black children are treated as special cases inside and outside schools rather than seen as "children in general" (Ferguson, 2000). They are significantly more likely to be viewed as adults, criminals, or other than human (Ferguson, 2000; Goff et al., 2014; Morris, 2016). As a result, Nelson (2020) argues, "we are unable to see Black boys as children whose actions communicate both met and unmet needs" (p. 6). These 
perceptions are so pervasive that Black boyhood - as a cultural identity, as a social experience, and as a subject of educational research — has been "rendered both unimagined and unimaginable" (Dumas \& Nelson, 2016, p. 28).

Education policy and practice consistently, fundamentally, and specifically reflect "a concern with the bodies of Black people, the signification of (their) blackness, and the threat posed by the Black to the educational well-being of other students" (Dumas, 2016, p. 12) Furthermore, predictably racialized patterns in school discipline are relational; they are the outcome of not only "treating Black youth as inherently suspect" but also of "treating White students as inherently innocent" (Diamond \& Lewis, 2016, p. 8). It is this presumed innocence that makes possible the presumed culpability of Black students.

The normative child is not only raced; she/he is gendered. For over a century critics have accused behavioral norms in schools of being hostile to and "feminizing" boys (Lesko, 2012). In fact, we have differing expectations of "good girls" and "good boys" from a very early age (Gansen, 2019; Martin, 1998; Thorne, 1993). As Walkerdine (1999) asserts, while the normative boy is "is playful, creative, naughty, rule-breaking, rational," the normative girl is "good, wellbehaved, and irrational" (p. 13). However, these feminine and masculine roles are also inflected by racial identification and domination (Carter Andrews, Brown, Castro, \& Id-Deen, 2019; Crenshaw, 1991; Deliovsky, 2008). Indeed, Black girls are viewed as less innocent and more disruptive than their white peers as early as age five (Epstein, Blake, \& González, 2017; Zimmermann, 2018).

These raced and gendered childhoods have deep and troubling implications for educators' differentiated perceptions of and responses to even very young children. Early childhood educators expect and look for more challenging behavior from Black children (Ferguson, 2000; 
Gilliam, Maupin, Reyes, Accavitti, \& Shic, 2016). Teachers are more likely to incorrectly perceive Black boys as "angry" when compared to Black girls, white boys, and white girls (Halberstadt et al., 2020). They are also more likely to focus on enforcing rules and delivering consequences, rather than facilitating relationships or rewarding positive behavior, with boys than girls (Dobbs, Arnold, \& Doctoroff, 2004; Erden \& Wolfgang, 2004). This may be related to the fact that schools and classrooms are generally led by white women, who might be more likely to identify with and presume innocence of children they see as like themselves (Annamma, 2015; Gilliam et al., 2016). However, racialized disciplinary patterns extend beyond the actions of individual educators or responses to particular students. Schools and districts with large populations of Black students are more likely to implement policies and practices that criminalize children; those with primarily white students are more likely to medicalize children and provide them with behavioral support plans (Ramey, 2015).

Researchers, policy makers, and practitioners have paid increasing attention to the ways schools discipline and exclude Black boys (Noguera, 2008; Owens \& McLanahan, 2019; Skiba, Arredondo, \& Rausch, 2014; US Department of Education, 2014). Yet we frequently overlook the relational nature of these meanings and systems, the ways raced and gendered inequalities are "produced in the relationships between dominant and subordinate groups" (Abu El-Haj, 2006, p. 12). Indeed, race is frequently considered salient by researchers and educators only when children are not white (Fine, 1997; Lewis \& Diamond, 2015). As a result, we know very little about how educators view and respond to "bad behavior" by white girls, particularly in the primary years.

\section{The Study and the Setting}


Gentrifying schools can be a particularly rich site for the examination of the raced and gendered development of children's reputations. School demographics frequently influence how educators interpret and respond to student behaviors (Carter, 2012; Fish, 2019; Morris, 2005b; Ramey, 2015). In schools where white students are demographic outliers, these interactions can become particularly complex (Freidus, in press; Freidus \& Noguera, 2017; Morris, 2005b). White kids in diversifying schools may take on dual but apparently conflicting roles: their difference renders them hypervisible (Ferguson, 2000; Shalaby, 2017), yet they serve as the normative ideal to which other children are compared. I examine how these dynamics manifest in kindergarten, the year in which reputations emerge that can follow children throughout the course of their schooling.

Ms. O'Shea, Hazel's teacher, was a white woman, who had taught at PS 411 for eleven years. In that time she witnessed many changes. When she arrived, the school served almost exclusively low-income Black and Latinx children who live in nearby public housing. However, as the surrounding neighborhood gentrified, a handful of primarily white, affluent families began to send their children to PS 411. When I collected these data in the 2016-2017 academic year, the school's student body was 61 percent Black, 33 percent Latinx, 5 percent white, and 1 percent Asian American. Most of the white students were in kindergarten, first, or second grade. 78 percent of the student body was eligible for free or reduced-price lunch.

I conducted observations at PS 411 for 51 days in the 2016-2017academic year, once or twice each week, typically for about 3 hours per visit. I followed Ms. O'Shea's students throughout the day, accompanying them to gym, art class, recess, and assembly. I jotted down bits of class dialogue, interactions, and conversations with kids and adults and then transcribed these jottings into formal field notes, writing reflective memos no more than 24 hours after each 
observation (Emerson, Fretz, \& Shaw, 2011). As the school year progressed, I interviewed 5 of the school's 7 teachers who worked with kindergarteners; 5 administrators and support staff; Hazel's and Marquise's mothers; and 6 of the 17 students in Ms. O'Shea's class. (Although I interviewed all 17 students in the class for interviews about their classroom experiences, their self-perceptions, and their perceptions of their peers, some were hesitant to participate, and others did not return the parental consent form. Marquise was one of the students who volunteered; Hazel was not.) In both formal interviews and informal conversations, I frequently asked participants about interactions I observed, checking my own interpretations and inviting participants' analyses. In my findings I share vignettes based on these field notes and interviews, at times juxtaposing my own observations with what students and teachers told me.

When I watched both students and teachers, I sought to be both "generous and tough, skeptical and receptive," aware of my roles as both an insider and an outsider in the school (Lawrence-Lightfoot, 2005, p. 5). As a former high school teacher, I was fully aware of the challenges of working in public schools. As a white, professional mother of a kindergartener, who lived in a recently gentrified neighborhood, I was highly attuned to racialized interactions in public schools. While my initial aim was to take a "least adult," nonauthoritative stance during observations, I frequently found it difficult to maintain that position (Mandell, 1988). At PS 411, staff frequently welcomed me in their classrooms because they wanted the presence of another adult. PS 411 educators, both Black and white, looked at me with evident disapproval when I did not discipline children who were breaking school or classroom rules in my presence. Over time, it became obvious that my stance strained my relationships with staff. In response to this tension and inspired by Lewis (2003), I began gently responding to moments of "misbehavior" with comments like, "We are all going to get in trouble" in an effort to align myself with kids while 
reminding them of classroom norms (p. 202). I also sought out opportunities to sit with students in small groups or one on one, which allowed me to observe students' behavior with less responsibility for managing it, while at the same time easing teachers' workloads.

While I was not seen as a teacher at PS 411—students called me "Ms. Alex," a naming convention they reserved for assistants and volunteers - neither was I seen as lacking adult authority. Kids were quick to treat me as a grown-up who could help them tie their shoes or resolve conflicts, despite my attempts to deflect those perceptions by encouraging them to find ways to solve problems on their own (a very adult strategy, to be honest). Kids' refusal to separate me from my status as a grown-up was justified. I did not have to ask permission to move around when I wanted to observe something across the room. And I sometimes lingered in the hallways during transitions, or sat in the classroom at lunchtime, chatting with teachers. Like other school ethnographers, on occasion I found myself drawing on my adult identities as a former teacher and a mother as I interacted with students (Ferguson, 2000; Thorne, 1993). And also like these ethnographers, I found myself at times remembering my own childhood and identifying with the kids I observed.

At the beginning of the school year, I was repeatedly struck by the ways Hazel and Marquise challenged the norms of their kindergarten classroom, which were focused on teaching children how to behave in school. Ms. O'Shea was very committed to maintaining a calm, orderly classroom. She spent a great deal of time making her expectations explicit; she regularly asked the class to practice following instructions, narrated the "good choices" that students made, and immediately corrected any perceived misbehaviors. During the hour of "Choice Time" every morning, she encouraged and praised creative play. During the rest of the day, she focused primarily on students' mastery of curriculum. In the first month of the school year, it 
became increasingly clear that although Hazel and Marquise were not the only students to break classroom rules, their behavior was the most likely to interrupt the steady hum of classroom routines. Intrigued by this pattern, I decided to incorporate a focus on Hazel's and Marquise's behaviors and the responses of adults and classmates into my observations and field notes.

At the close of data collection, I used Dedoose qualitative software to identify the repetitive refrains (e.g., "the only one"), resonant metaphors (e.g., "a brick wall”), and classroom rituals (e.g., sitting on the rug) related to these two children's behaviors (Lawrence-Lightfoot \& Davis, 1997). I then categorized these coded data according to Maclure et al.'s (2012) frames of disposition, medicalization, and family and community and wrote a series of memos connecting each code to the children's reputations.

\section{Hazel}

\section{Hazel's Disposition: "She Was the Only One"}

Ms. O'Shea strongly believed in the power of clearly communicating what she thought about students' behavior. Throughout the school day, she frequently used praise and "positive narration" to publicly highlight behaviors she wanted students to repeat and quickly corrected behaviors she wanted to eliminate. Although she later came to view Hazel as a child with a problem, she initially deemed Hazel's behavior ideal, holding her up as a role model for her peers. On the very first day of school, Ms. O'Shea told the class that Hazel was "really good" because she had figured out where to put things away without asking. In fact, she praised Hazel's classroom behavior almost every day I observed: “Thank you, Hazel! . . . I see Hazel's ready and waiting!" In doing so, she frequently made Hazel's exceptionality quite explicit: "Hazel went right to her spot, sat criss-cross applesauce, and kept her voice off. She was the only one." While 
the positive narration generally focused on Hazel's actions rather than her disposition, the sheer volume and consistency of teacher praise sent an unambiguous message that Hazel was a "good" student. Other PS 411 staff also frequently commented on Hazel's adherence to school rules, telling her she was doing a great job waiting quietly in line or sitting quietly in the cafeteria. This public praise of Hazel's behavior was a powerful reminder that "goodness" is generally marked by compliance - a key feature of white femininity (Carter Andrews et al., 2019). As the only white kindergarten girl in her gentrifying school, Hazel was already likely to draw adult attention; her emerging reputation for docility made her even more so.

Hazel frequently received praise for not only what she did but also what she did not do. In addition to calling her "always ready," Ms. O'Shea told the class several times that Hazel's "brain focuses on the right thing." Indeed, one day when the class was sitting on the rug, one student pouted and dramatically sighed, "Ohhhhh," after the teacher chose Hazel to read out loud. Ms. O'Shea was quick to reprimand the girl, asking pointedly, "Does Hazel ever do that when you're called on?" The child silently shook her head no. In general, Hazel's classmates quickly came to share adults' positive perceptions of her disposition.. When I asked the six children I interviewed to name their three closest kindergarten friends, five included Hazel on their list. However, Hazel was not only popular. Her peers were also confident that Hazel would always be correct, even when responding to questions that lacked obvious "right answers," such as predictions about what might happen in a book. As one of her tablemates explained to me, she was always “doing good.” Hazel had the reputation of being an exceptional kindergartener.

Yet, despite the consensus on Hazel's disposition, there were multiple moments each day that led educators to question her behavior. For three months, Hazel could not make it through the entire school day without breaking down into expansive, extended crying jags. Adults and 
kids were concerned about her palpable discomfort; school staff discussed her behavior in murmured tones, and her peers offered hugs when she started sobbing. After the first few days of school, Hazel began clinging to her mother or father at drop-off, refusing to enter the classroom. On several occasions she took off running down the hallway, until her parent chased after her, corralled her, and returned her to the classroom. Soon, Ms. Diana, a white woman who was the assistant principal in charge of primary grades, began taking Hazel to her office at the start of each school day, playing games with her and slowly coaxing her to return to class. However, one day in early October, when Ms. Diana was occupied elsewhere, Hazel simply refused to enter the classroom. When Ms. O’Shea insisted that she come in, Hazel became violent, kicking and trying to bite her teacher. This defiant behavior did not fit with Hazel's reputation for goodness, and so Hazel's teachers and parents searched for an alternate explanation.

\section{Hazel's Diagnosis: “Anxiety Is a Terrible Emotion”}

When Hazel's misbehavior at drop-off began to escalate, rather than resolve over time, Ms. Diana and Ms. O'Shea encouraged her family to request the support of a child psychologist. Hazel's parents quickly agreed. Dr. Medina, a white woman, was at the school several days each week as part of a community partnership intended to support low-income children, but she was available to treat any child in crisis. After she had observed Hazel in the classroom and met with her several times, Dr. Medina diagnosed her with anxiety. She counseled both Hazel and her parents (separately and together) for several months and also supported Ms. O'Shea with strategies to increase Hazel's comfort in the classroom.

Ms. O'Shea repeatedly returned to Hazel's diagnosis to make sense of her behavior. As a matter of principle, she expected children to take responsibility for their actions. She spoke 
frequently to the class about the importance of making good choices and was quick to deliver immediate consequences when children misbehaved. When she discussed Hazel's classmates, she usually followed frustrated descriptions of misbehavior with conclusions about flaws in the kid's dispositions. However, this was not the case when Ms. O'Shea talked about Hazel.

After school one day in October, Ms. O’Shea caught me up on some events I had missed the week before. She told me that Hazel had had a series of "wild and wicked temper tantrums," one day screaming, “I hate Ms. O’Shea! I hate Ms. O’Shea! I don’t want to stay with her! I hate school!" Then Hazel had tried to bite her. As she told me this story, Ms. O'Shea shrugged. She said that it was okay for Hazel not to like her, that she knew that "anxiety is a terrible emotion." She paused, correcting herself_ “state of mind." It seemed that, in Ms. O'Shea's eyes, Hazel's diagnosis relieved her of responsibility for her behavior, shaping not only how her teacher responded to Hazel but also how she characterized Hazel's disposition. This made it possible for Hazel to preserve her reputation for innocence despite actions that might have tarnished the reputations of her peers.

The discursive frame of medicalization shaped both official responses and unofficial responses to Hazel's behavior. After Hazel kicked Ms. O'Shea, Ms. Diana sat down with Hazel's parents and Ms. O'Shea. They were there not to settle on a punishment but to make a plan. Together, they decided that until Hazel's anxiety about school had subsided, she would leave kindergarten at lunch time each day. When I asked Ms. Diana several months later how they had reached this decision, she told me, "We needed to support Hazel. We needed to support the family. We needed to work out a plan." I wondered aloud how it was possible to just decide that Hazel could leave midway through the day. Wasn't it against the rules? Ms. Diana told me that when she told other administrators about the plan, "I didn't have anybody telling me no, because 
the focus is what's right for this child." But then she paused and noted that somebody from the Department of Education had explicitly told her that "you cannot have a pre-K child come for half a day without permission from the DOE.” However, Ms. Diana said with a smile, nothing had been said about kindergarteners, and she hadn't asked. It appeared that the discursive frame of medicalization did more than facilitate a view of Hazel's behavior as beyond her control. It allowed staff to relax rules that might otherwise have been quite rigid (as they were in the case of Marquise). By offering flexible support and extending accommodations to Hazel and her family, staff at the gentrifying school treated these newcomers to the community as "valued customers" (Cucchiara, 2013).

Rather than criminalizing Hazel's behavior, the school took a diagnostic and therapeutic approach that affirmed her innocence. She received an individualized program of half-day kindergarten until the week after Thanksgiving, when she suddenly stopped asking to go home early, to her parents' and teachers' great joy. Her classmates accepted without question that Hazel went home early every day for three months and did not comment much when she left class to talk with Dr. Medina. Perhaps because she was only available sometimes, playtime with Hazel seemed to become even more desirable. When she returned to class, her friends frequently rushed over to give her hugs, at times overwhelming her. Ms. O'Shea was quick to protect Hazel, telling the class that they needed to give her a little more space.

\section{Hazel's Family and Community: "A Very Secure Home Life"}

School staff's perceptions of Hazel seemed tightly tied to their perceptions of her family. In interviews, the principal, Ms. Diana, and Ms. O'Shea all distinguished Hazel from many of her classroom peers. Ms. Diana explained that "a child like Hazel obviously is - experiences 
things with her parents. Her parents talk to her. She has a very secure home life." She explicitly juxtaposed Hazel's home with that of "a lot of our kids" whose "parents talk at them rather than to them." I probed further.

Alex: So, you weren't worried or aren't worried about Hazel in the way that you'd be worried about the other kids?

Ms. Diana: No. No, I didn't see anything else. I really saw that she was just struggling with anxiety. I didn't feel that she was not being taken care of. We have kids who come in here who just reek. They haven't been bathed. They come in for breakfast. They're ravenous. Some kids who would just eat all day if we let them.

Alex: It's a different situation?

Ms. Diana: Yeah, and again, that's socioeconomic. [pause] I don't know if that's exactly the right way to say it or-For Hazel it was just that really severe anxiety.

Because the student body at PS 411 was gentrifying, staff had abundant opportunities to compare their perceptions of the home lives and communities of newcomers and long-time residents. Ms. O'Shea, like Ms. Diana, periodically noted the differences between students who lived in the gentrifying area of the school zone and those who lived "down the street" in nearby public housing. Hazel's presence within the school appeared to throw into relief he dysfunction that educators perceived among her classmates, such as Marquise. Ms. Diana was quite confident that Hazel's family was innocent; unlike the families of her peers, they could not be held responsible for her problems. What is more, she perceived Hazel's behavior as an individual problem rather than a symptom of community pathology. Hazel's reputation was thus intricately linked to that of her family and, more broadly, her race and socioeconomic status. 
Other members of PS 411 were more likely to locate some of the responsibility for Hazel's behavior in her family's response, even though they also viewed them sympathetically. Ms. O'Shea told me that Hazel had "good parents" who were "caring, kind people" who seemed "firm" when necessary. However, she also believed that they inadvertently encouraged Hazel's behavior. Ms. Knox, the school security guard, was sure that Hazel's parents were themselves quite anxious. A Black woman who had worked at the school for over a decade, Ms. Knox was a beloved member of the school community who welcomed kids and families warmly each morning and watched over students as they passed throughout the day. When I asked her what she had noticed about Hazel during drop-off, she first described Hazel's attempts to run away and then explained:

I told her mother, I said, "You gotta leave her. You gotta leave her because she has to know that you mean business. It hurts you because [of] this anxiety and separation. However, you have to let her know that it's okay ... because she has to learn how to be alone and okay at the same time" ... When Dad brought her, Dad would, like, fall to pieces. I said, "Dad, she'll be okay. If you want to, you can leave the classroom, but you don't have to leave the building. And just walk back in and check and see, check on her." And he did, and he was like, "Well, she's okay." I said, "She'll be okay."

Ms. Knox and Ms. O’Shea considered Hazel's parents to be somewhat indulgent. They implied that Hazel's separation anxiety was not an anomaly and was rooted in ongoing family dynamics. However, they continued to empathize with Hazel and her family. Perhaps because they were convinced that Hazel's family, like other neighborhood newcomers, had "a very secure home life" without any "socioeconomic" concerns, they were reluctant to consider Hazel's parents culpable for her behavior. 
As I observed, I often noted differences between how the school treated Hazel and her peers. Hazel's mother told me with great enthusiasm that PS 411 had been "so supportive" of their family. She marveled at the "time and energy" that Ms. O'Shea, Ms. Diana, and Dr. Medina spent on her daughter and thought it "extraordinary" that they treated Hazel "as a little individual" who needed their help. Hazel's mother, who talked primarily with other newcomer families, did not seem to consider how important her family's continued presence at PS 411 may have felt to school staff. Many gentrifying schools see attracting and retaining neighborhood newcomers as a priority; these families are viewed as important sources of economic and social resources (Cucchiara, 2013; Freidus, 2019, 2020; Posey-Maddox, 2014). Similar considerations may have played a role in PS 411's willingness to be flexible and supportive with Hazel and her family.

It is worth noting that when Hazel took a break from class by going to Ms. Diana's or Dr. Medina's office, she went to some of the only support spaces at PS 411 that were under the care of white women. This was far from inevitable: five of the six other administrators and support staff at the school were people of color. However, Ms. Diana was the assistant principal in charge of kindergarten, and it was she who referred Hazel's family to Dr. Medina for help. Perhaps by chance, Hazel was placed from the beginning in Ms. O'Shea's classroom rather than in the classes of the three other kindergarten teachers, who were all women of color. It is possible that Hazel's racial and gender match with Ms. O’Shea, Ms. Diana, and Dr. Medina facilitated their expectations of and identification with her, as well as her identification with them ( Gilliam et al., 2016; Wright, Gottfried, M. A., \& Le, 2017). 
Indeed, the school's willingness to provide Hazel with flexible support may in part have been because Ms. O'Shea and her colleagues seemed to see Hazel and her family as people very much like themselves. Early in the year, Ms. Diana told me that her own son had "pretty tough separation anxiety," and that's how she knew both how to help Hazel and how challenging it might be for her family. Ms. O’Shea nurtured a relationship with Hazel based on shared experiences. When Hazel brought in a cream cheese and jelly sandwich for lunch, for example, Ms. O'Shea smiled and said that her own mom used to make that sandwich for her when she was little. This interaction stood in marked contrast to Ms. O'Shea's running commentary about the food Hazel's classmates brought from home that she deemed "unhealthy," a label often assigned to the feeding and parenting practices of women of color (Elliott \& Bowen, 2018). Indeed, Ms. Diana and Ms. O'Shea were quick to note deficits in Hazel's classmates, their families, and the subsidized housing residents that the school had long served, as many white educators do with low-income students and families of color (Nelson, 2020; Valenzuela, 1999). Yet they did not name the deficits of Hazel, her parents, or newcomer families in general. The binary of Black culpability and white innocence — which these white women also benefited from — appeared to extend beyond individual students' reputations to the reputations of their communities.

\section{Marquise: A Counternarrative}

School staff applied the logics of disposition, medicalization, and family and community less generously with Hazel's classmates. Marquise, for example, was a Black boy in Hazel's class who quickly acquired a reputation for being a problem child. In some ways, Marquise stood out much less at PS 411 than Hazel did. One of seven Black boys in his class, he, like the majority of his classmates, lived in the housing projects down the street from the school. Tall and 
stocky, Marquise had dark skin, a round face, and close-cropped hair. He smiled easily and was quick to hug both grown-ups and kids. He was also quick to point out when he didn't agree with adults' decisions.

On the first day of school— the same day Ms. O'Shea exclaimed that Hazel was "really good!"-Ms. O'Shea made clear that Marquise was not meeting her expectations for classroom behavior. After she asked him several times to "redo" how he moved around the room during transitions between activities, Marquise rebelled, loudly saying, "No!" Ms. O’Shea immediately pulled him aside and told him, "In this room, we do what grown-ups tell us. If I tell you to do something or Ms. Alex asks you to do something, you say 'Yes, Ms. O’Shea' and you do it. We need to practice this a lot of times so that you can get it right." Then she had Marquise cross the room to the rug and back again and again, letting him know when he had it "almost right" and then praising him highly when he did it "perfectly." When Marquise's mother came to pick him up, Ms. O'Shea gave her a full report . His mother was quick to tell Marquise that he must always say, “Yes, Ma’am!” when Ms. O’Shea asked him a question.

But over the next few weeks, Marquise repeatedly breached classroom norms in large and small ways: he refused to sit in his assigned rug spot; he interrupted class discussions; he yelled when he did not get to go to the activity center of his choice. Ms. O'Shea tested many strategies for gaining Marquise's compliance. She volubly praised him or gave him stickers as rewards for following directions; she called his mother on speaker phone to describe his misbehavior; she kept him in from recess; she allowed him to have a midmorning snack even though other kindergarteners waited until lunchtime to eat. Nothing seemed to work. There were times when Marquise lay down on the floor wailing loudly and violently kicking his legs, interrupting all other classroom activity. Over the course of September, Ms. O’Shea invested much of her time 
in trying to control Marquise's behavior. At least once a week, she asked Ms. Knox to remove Marquise from class and take him somewhere so he could calm down.

Ms. O’Shea was very frustrated. She had been teaching young children for more than a decade and was not used to struggling with classroom management. She looked for alternative explanations for Marquise's actions. In search of a diagnosis, she told me that Marquise must have "special needs, ADHD, I don’t know." She told me with rising exasperation that Marquise should not be in her classroom because he needed a "special setting." She asked Ms. Orozco, the school's special education coordinator, to observe Marquise in class and confirm her suspicions. However, Ms. Orozco told Ms. O’Shea that Marquise showed no signs of a disability. Rather, she concluded that Marquise's behavioral choices were a consequence of "learned behavior."

Moving from a medicalized approach to a disciplinary approach, Ms. O’Shea sat down with Marquise's mother to create a plan that would hold the family responsible for his behavior. In the classroom, they assigned a corner for Marquise to go to when he was angry that included a personalized "feelings book" with photos of Marquise and a sticker chart marking his progress. At the same time, Ms. Orozco warned Ms. O'Shea that "Mom is not going to keep her end of the bargain," so it would take a long time for the behavior plan to work. Although PS 411 staff were reluctant to assign blame in Hazel's case, they were quick to do so in Marquise's case. Both Marquise and his family had established reputations.

Near the end of the school year, I asked Ms. O’Shea if she or Ms. Orozco had ever considered referring Marquise to Dr. Medina. They had not, they told me, although they had asked a Black, male counselor to provide occasional classroom support. This struck me as surprising given how swiftly Hazel had been referred to the psychologist. There appeared to be significant differences in not only the two children's reputations but also in the school's resource 
allocation. Dr. Medina was placed in a gentrifying school to provide counseling to children who lived in public housing, such as Marquise, yet teachers had not requested her support with him as they had with Hazel.

One day in early November, Ms. O'Shea told me that during my absence from the classroom the day before, Marquise had tried to "beat me up"; he had attempted to kick, hit, and bite her. After this incident, the principal assigned a paraprofessional to work with Marquise, although she made it clear that she did not have the funding to sustain this intervention. Slowly, incrementally, and not at all linearly, Marquise's behavior began to change, even after his aide was reassigned several weeks later. Soon after the paraprofessional left, however, Marquise hit another student. Fed up, Ms. O'Shea filed an incident report, and Marquise received an in-school suspension. For two days he sat in the office with Mr. Williams, a Black man who had been the school's parent coordinator for fifteen years.

Ms. O'Shea, Mr. Williams, and Marquise's mother all considered that disciplinary event a turning point, telling me that Marquise was "a changed boy" when he returned to the classroom two days later. At the end of the year, Ms. O'Shea told me that after his suspension, Marquise shifted his behavior:

You could see him, when he was gearing up to make a choice, kind of slow down and remember how uncomfortable it was to not be with his class, and he would pivot. I think that was the tipping point. I think he got a lot of support, and that helped, but he ultimately needed to hit a brick wall.

Ms. O'Shea attributed the change in Marquise to his learning that there were consequences for his actions. She understood Marquise to be "making a choice," and so she held him responsible for his behavior in a way she did not hold Hazel responsible for hers. 
Like Ms. O’Shea, Mr. Williams agreed that Marquise needed to feel consequences for his behavior. However, he attributed the intervention's success to another factor: love. He told me what Marquise, and other children, "needed to hear":

“Hey, I'm concerned about you. When I tell you 'I love you,' I really love you. This is not-I'm not telling you this so I can get you to do some work. No. On top of my six children at home, I have 398 other children in here.” And they all [the students] know this. "My love for you runs deep like that. I want to see you excel, and I'm going to do everything I possibly can to help that" . . Now Marquise loves me. He trusts me. He knows, "If I do good, Mr. Williams is going to be right there with me, and if I do bad, he's going to get on me. But he's not going to leave me. He's still going to have my back." And that's all children want to know.

Ms. O'Shea had emphasized the "brick wall" of a disciplinary consequence in her account of Mr. Williams's intervention; she was more interested in removing Marquise from the classroom community than in what Mr. Williams said to Marquise. But Mr. Williams believed that it was the relationship he and Marquise developed during that time that changed the boy's behavior (Nelson, 2020). Marquise's mother agreed. She told me that "Mr. Williams . . . didn't make him feel bad about" the in-school suspension. He told Marquise, "You may hate being in here, but you're gonna be my friend. We gonna be cool. We gonna do this."

Unlike many educators, Mr. Williams was not interested in naming and diagnosing the many ways Marquise deviated from the "normal developmental course" (MacLure et al., 2012, p. 455). Instead, he focused on what Marquise had in common with his peers: his childhood. By approaching discipline from a protective stance (McKinney de Royston, Madkins, Givens, \& 
Nasir, 2020), Mr. Williams reimagined schooling as a site of possibility for Marquise (Dumas \& Nelson, 2016). His goal was that Marquise experience a caring and supportive relationship with school, despite the behavioral challenges he presented. He wanted Marquise to know that he had his back. Mr. Williams believed that Marquise, like Hazel, should be recognized as a child (Nelson, 2020).

However, Marquise's reputation for “being bad," as his peers described it, had already been thoroughly established within the school community. School staff emphasized the importance of offering Hazel flexible support when she ran away or acted violently at the classroom door. With Marquise, however, adults were constantly on the lookout for misbehavior. When I stopped at the school entrance one afternoon to ask Ms. Knox how she was doing, the first thing she told me was that the day had gone smoothly because Marquise had been calm all day. His peers were equally aware of Marquise's reputation. When I asked other kindergarteners in interviews to name someone who behaved badly in class, four out of five named Marquise, citing his lack of compliance with rules, his tendency to hit when frustrated, and his poor listening skills. Indeed, one girl told me that she loved Ms. O'Shea because "when Marquise is hitting or fighting or hitting a person, Miss O'Shea protects us." They saw him very differently than they saw Hazel, who needed protection. When I interviewed Marquise in March, he told me that earlier in the year Ms. O'Shea sometimes had to "talk to me," and when that happened he wouldn't "have a choice to make." However, he proudly told me, "I always be good.” Despite the ways he had been labeled otherwise by his school, Marquise was sure of his own goodness. Marquise's path from problem child to in-school suspension echoes many well-known storylines about the raced and gendered discipline gap. Mr. Williams's love for his students was a crucial intervention, one that reshaped the trajectory of Marquise (and many of his peers) at PS 
411. However, that relationship alone was not enough to change Marquise's reputation. A conversation I had with several administrators at the end of the year illustrated its power. I asked the educators what they thought had happened with Hazel and Marquise. An assistant principal told me that "Hazel had difficulty, you know, detaching from her family. Marquise coming in was maybe a little erratic." The principal agreed. She made an offhand reference to the time that Marquise kicked Ms. O’Shea. I told her that it was Hazel who had kicked Ms. O'Shea, and she was very surprised: “Oh, she kicked Ms. O’Shea? Oh, I thought Marquise was the one who kicked Ms. O’Shea . . . Isn't that interesting!” The principal was so sure that Marquise had been the culprit; it was hard for her to reconcile Hazel's actions with her reputation for innocence.

\section{Conclusion}

Both Hazel and Marquise breached school norms during their transition into kindergarten, disrupting instructional activities and at times acting aggressively toward their teacher. In both cases, educators tried multiple strategies to shape their behavior. What interests me here are the material consequences of the differences between the two children's reputations. While Hazel became known for her "anxiety," Marquise was disciplined for his "learned behavior." School staff met with Hazel's parents to discuss their concerns; they met with Marquise's mother to create a behavior plan. Ms. O'Shea consulted with a child psychologist about Hazel's behavior; she referred Marquise for observation by the special education coordinator. Administrators created a modified schedule for Hazel; they sent Marquise to an inschool suspension. The disciplinary apparatus that seemed to unfurl, almost automatically, for Marquise was never considered in Hazel's case. Rather than being deemed a problem child, Hazel became known as a child with a problem. She was given the "silent benefit of the doubt" 
(Diamond \& Lewis, 2016, p. 18). As a result, Hazel was offered a pathway of support, counseling, and protection that was not extended to Marquise — or to the other Black children in that kindergarten class. For while Marquise's suspension was the most extreme example of discipline in Ms. O'Shea's room, he was not the only Black child she saw as deficient. Marquise was one of two Black children who were periodically removed from the classroom for bad behavior, one of three Black children Ms. O'Shea saw as candidates for special education, and one of seven whom she described as victims of poor parenting.

Hazel's and Marquise's divergent trajectories during their transition into formal schooling illustrate the extent to which white innocence is coproduced with Black culpability. The same discourses of disposition, medicalization, and family and community that assigned Marquise and his family responsibility for his actions protected Hazel and her family from responsibility for hers. The two cases are intertwined. In this gentrifying school, Hazel's race and class status placed her firmly within the category of "children in general" (Ferguson, 2000). In contrast, the normative frames that presumed Hazel innocent also denied Marquise the "protections of childhood" (Goff et al., 2014, p. 527) and contributed to his exclusion from innocence. Instead, he was subjected to suspicion and surveillance and repeatedly told he did not belong within the classroom community (Annamma, 2015; Meiners, 2017; Shalaby, 2017).

I do not share Hazel and Marquise's stories as an indictment of educators, nor do I hold individuals solely responsible for the structural inequalities and racist discourses that saturate many schools. Indeed, during my time at PS 411, the school was full of well-intentioned people who saw the work of teaching low-income children of color and promoting school integration as an antiracist endeavor. However, teachers and schools inevitably are influenced by and participate in the logics of white innocence and Black culpability, despite their best intentions 
(Lewis \& Diamond, 2015). When the misbehavior of Black boys in school signifies that they are headed to the "jailhouse" (Ferguson, 2000), it elicits responses based on the criminal justice system. Indeed, special education spaces such as those to which Ms. O'Shea referred Marquise all too often serve as little more than holding cells for Black students (Watts \& Erevelles, 2004). In contrast, it is not surprising that PS 411 would draw on the principles of the mental health system in their responses to Hazel, given that the normative (white) girl is known as "good, wellbehaved, and irrational" (Walkerdine, 1999, p. 13). Nobody felt the need to teach Hazel a lesson; they just wanted to help a little girl and her family.

While "troublemakers" are often punished for their hyper visible behavior (Ferguson, 2000; Shalaby, 2017), Hazel appeared to benefit from her own hypervisibility. Her exceptionality within the school community brought her additional accommodations. PS 411 staff, like educators in many gentrifying schools, felt it was important to treat newcomers like Hazel as "valued customers" (Cucchiara, 2013). They didn't mind bending rules, investing time, or providing special services to support Hazel and her family. This is, perhaps, unsurprising. We know that schools with large numbers of Black and poor students are likely to approach discipline through the principles of the criminal justice system (Ramey, 2015). We also know that gentrifying schools, like most racially and socioeconomically diverse schools, are likely to treat white middle-class families more deferentially than they treat their low-income peers of color (Cucchiara, 2013; Lewis \& Diamond, 2015; Posey-Maddox, 2014; Quarles \& Butler, 2018). Hazel and her handful of white peers paradoxically played the role of both the norm and the outlier at PS 411; they were seen as both reference points for how children should be and as highly valued sources of social, cultural, and economic capital for the school's other students (Freidus, 2019; Lipman, 2008). Perhaps as a consequence, Hazel's behavioral concerns were 
seen as a signal that she was a child with a problem, and it was the school's job to address this. PS 411's shifting demographics, together with the tendency of gentrifying schools to cater to newcomer families, rendered racialized school discipline norms, values, and practices particularly visible.

As I sat on the classroom rug or perched with kids at tables, I frequently wondered what the other children in the class learned from observing these interactions. In interviews and observations, kids clearly demonstrated their understanding that Hazel, white and female, was good, while Marquise, Black and male, was not. They knew that students were responsible for making good choices and that Marquise repeatedly failed to do so. They understood that if you made bad choices, there would be no place for you within the classroom community (Shalaby, 2017). They believed that they needed protection from children like Marquise. And they learned to be patient and flexible with children like Hazel, who required and deserved their protection. They learned the twinned lessons of white innocence and Black culpability.

Hazel's and Marquise's stories teach us that to fully understand the differences in how Black and white children are disciplined, we need to look closely not only at how we disproportionately punish some students but also at the allowances and affordances we make for others. What might it take to remake these relational categories of innocence and culpability, whiteness and Blackness? What might it take for schools - and all of us - to extend the same generosity and flexibility to Marquise that PS 411 gave so freely to Hazel? Mr. Williams reminds us of one answer. We might show them, "My love for you runs deep like that. I want to see you excel, and I'm going to do everything I possibly can to help that."

In order to see children excel, we must reconsider the hidden curriculum of school discipline. Rather than locating the problem in children's behavior, we must examine schools' 
norms and practices (Abu El-Haj, 2006). We must track when and why we decide to direct additional resources toward some kids and not others, monitoring how we offer access to mental health services to students like both Hazels and Marquises. We must ask which kids have access to protective relationships with school staff and which do not (McKinney de Royston et al., 2020). We must reconsider where we locate expertise in schools. How could we support students by drawing on the skills and knowledge of not only psychologists and learning specialists but also parent coordinators and paraprofessionals?

Having considered these preliminary questions, we might then seek help from support staff like Mr. Williams and Ms. Knox who use their familiarity with a neighborhood's past and present to support both old-timers and newcomers to the school community. We might seek to approach all students' families as knowledgeable members of a shared team rather than see them as undisciplined individuals themselves in need of remediation. We might reconsider what children are learning when they are told a "good student" is one who "keeps her voice off." We might be willing to bend or change the rules for more kids if they do not serve our goals for learning, safety, and growth. We might refuse to use exclusion as a tool for social control. We might repeatedly demonstrate that all kids belong in the classroom community. We might see them as good.

\section{Notes}

1. Throughout I capitalize Black but not white. As Crenshaw (1991) argues, Black and African American denote a specific cultural group in the contemporary United States (p. 1244n6). In contrast, white describes multiple cultural groups (e.g., Irish, Italian, French) and refers singularly to a shared role in an oppressive system (Dumas, 2016, p. 13) 
2. All names are pseudonyms. I have also slightly altered some details for the purpose of protecting the identity of individuals.

\section{References}

Abu El-Haj, T. R. (2006). Elusive justice: Wrestling with difference and educational equity in everyday practice. New York: Routledge.

Annamma, S. A. (2015). Whiteness as property: Innocence and ability in teacher education. The Urban Review, 47(2), 293-316. doi:10.1007/s11256-014-0293-6

Broderick, A. A., \& Leonardo, Z. (2016). What a good boy: The deployment and distribution of “goodness" as ideological property in schools. In D. J. Connor, B. A. Ferri, \& S. A. Annamma (Eds.), DisCrit: Disability studies and critical race theory in education. New York: Teachers College Press.

Carter, P. L. (2012). Stubborn roots: Race, culture, and inequality in U.S. and South African schools. New York: Oxford University Press. doi:10.1093/acprof

Carter Andrews, D. J., Brown, T., Castro, E., \& Id-Deen, E. (2019). The impossibility of being “perfect and white”: Black girls' racialized and gendered schooling experiences. American Educational Research Journal, 56(6), 2531-2572. doi:10.3102/0002831219849392

Crenshaw, K. (1991). Mapping the margins: Intersectionality, identity politics, and violence against women of color. Stanford Law Review, 43(6), 1241-1299.

Cucchiara, M. B. (2013). Marketing schools, marketing cities: Who wins and who loses when schools become urban amenities. Chicago: University of Chicago Press.

Deliovsky, K. (2008). Normative white femininity: Race, gender and the politics of beauty. Atlantis: Critical Studies in Gender, Culture \& Social Justice, 33(1), 49-59. Retrieved from http://journals.msvu.ca/index.php/atlantis/article/view/429/422 
Diamond, J. B., \& Lewis, A. E. (2018). Race and discipline at a racially mixed suburban high school: Status, capital, and the practice of organizational routines. Urban Education, 54(6), 831-859. doi:10.1080/0161956X.2016.1184951

Dobbs, J., Arnold, D. H., \& Doctoroff, G. L. (2004). Attention in the preschool classroom: The relationships among child gender, child misbehavior, and types of teacher attention. Early Child Development and Care, 174(3), 281-295. doi:10.1080/0300443032000153598

Dumas, M. J. (2016). Against the dark: Antiblackness in education policy and discourse. Theory into Practice, 55(1), 11-19. doi:10.1080/00405841.2016.1116852

Dumas, M. J., \& Nelson, J. D. (2016). (Re)Imagining Black boyhood: Toward a critical framework for educational research. Harvard Educational Review, 86(1), 27-47. doi:10.17763/0017-8055.86.1.27

Elliott, S., \& Bowen, S. (2018). Defending motherhood: Morality, responsibility, and double binds in feeding children. Journal of Marriage and Family, 80(2), 499-520. doi:10.1111/jomf.12465

Emerson, R. M., Fretz, R. I., \& Shaw, L. L. (2011). Writing ethnographic fieldnotes (2nd ed.). Chicago: University of Chicago Press.

Epstein, R., Blake, J. J., \& González, T. (2017). Girlhood interrupted: The erasure of Black girls' childhood. Georgetown Law Center on Inequality and Poverty. Retrieved from https://ssrn.com/abstract=3000695

Erden, F., \& Wolfgang, C. H. (2004). An exploration of the differences in prekindergarten, kindergarten, and first grade teachers' beliefs related to discipline when dealing with male and female students. Early Child Development and Care, 174(1), 3-11.

doi:10.1080/0300443032000103098 
Ferguson, A. A. (2000). Bad boys: Public schools in the making of Black masculinity. Ann Arbor: University of Michigan Press.

Fine, M. (1997). Witnessing whiteness. In M. Fine, L. Weis, \& L. M. Wong (Eds.), Off-white: Readings on race, power, and society (pp. 58-65). New York: Routledge.

Fish, R. E. (2019). Standing out and sorting in: Exploring the role of racial composition in racial disparities in special education. American Educational Research Journal, 56(6), 2573-2608. doi: $10.3102 / 0002831219847966$

Freidus, A. (2019). “A great school benefits us all”: Advantaged parents and the gentrification of an urban public school. Urban Education, 54(8), 1-28. doi:10.1177/0042085916636656

Freidus, A. (2020). Modes of belonging: Debating school demographics in gentrifying New York. American Educational Research Journal, 57(2), 808-839. doi: $10.3102 / 0002831219863372$

Freidus, A. (in press). Looking smart: Race and academic ability in a diversifying middle school. Teachers College Record.

Freidus, A., \& Noguera, P. A. (2017). Making difference matter: Teaching and learning in desegregated classrooms. The Teacher Educator, 52(2), 99-113. doi:10.1080/08878730.2017.1294925

Gansen, H. M. (2019). Push-ups versus clean-up: Preschool teachers' gendered beliefs, expectations for behavior, and disciplinary practices. Sex Roles, 80(7), 393-408. doi:10.1007/s11199-018-0944-2

Gilliam, W. S., Maupin, A. N., Reyes, C. R., Accavitti, M., \& Shic, F. (2016). Do early educators' implicit biases regarding sex and race relate to behavior expectations and recommendations of preschool expulsions and suspensions? Yale University Child Study 
Center 9(28).

Goff, P. A., Jackson, M. C., Di Leone, B. A. L., Culotta, C. M., \& DiTomasso, N. A. (2014). The essence of innocence: Consequences of dehumanizing black children. Journal of Personality and Social Psychology, 106(4), 526-545. doi:10.1037/a0035663

Gregory, A., Skiba, R. J., \& Noguera, P. A. (2010). The achievement gap and the discipline gap: Two sides of the same coin? Educational Researcher, 39(1), 59-68. doi:10.3102/0013189X09357621

Halberstadt, A. G., Cooke, A. N., Garner, P. W., Hughes, S. A., Oertwig, D., \& Neupert, S. D. (2020). Racialized emotion recognition accuracy and anger bias of children's faces. Emotion. doi: $10.1037 / \mathrm{emo} 0000756$

Hatt, B. (2012). Smartness as a cultural practice in schools. American Educational Research Journal, 49(3), 438-460. doi:10.3102/0002831211415661

Jackson, P. (1968). Life in classrooms. New York: Holt, Rinehart \& Winston.

Lawrence-Lightfoot, S. (2005). Reflections on portraiture: A dialogue between art and science. Qualitative Inquiry, 11(1), 3-15. doi:10.1177/1077800404270955

Lawrence-Lightfoot, S., \& Davis, J. H. (1997). The art and science of portraiture. San Francisco: Jossey-Bass.

Lesko, N. (2012). Act your age! A cultural construction of adolescence (2nd ed.). New York: Routledge.

Lewis, A. E. (2003). Race in the schoolyard: Negotiating the color line in classrooms and communities. New Brunswick, NJ: Rutgers University Press.

Lewis, A. E., \& Diamond, J. B. (2015). Despite the best intentions: How racial inequality thrives in good schools. New York: Oxford University Press. 
Lipman, P. (2008). Mixed income schools and housing: advancing the neoliberal urban agenda. Journal of Education Policy (23)2, 119-134.

MacLure, M., Jones, L., Holmes, R., \& Macrae, C. (2012). Becoming a problem: Behaviour and reputation in the early years classroom. British Educational Research Journal, 3(3), 447471. doi:10.1080/01411926.2011.552709

Mandell, N. (1988). The least-adult role in studying children. Journal of Contemporary Ethnography, 16(4), 433-467. doi:10.1177/0891241688164002

Martin, K. A. (1998). Becoming a gendered body: Practices of preschools. American Sociological Review, 63(4), 494-511.

McKinney de Royston, M., Madkins, T. C., Givens, J. R., \& Nasir, N. S. (2020). 'I'm a teacher, I'm gonna always protect you': Understanding Black educators' protection of Black children. American Educational Research Journal, XXXX(XX), 1-39. doi: $10.3102 / 0002831220921119$

Mehan, H. (1980). The competent student. Anthropology \& Education Quarterly, 11(3), 131152. doi:10.1525/aeq.1980.11.3.05x1865s

Mehan, H. (1996). Beneath the skin and between the ears: A case study in the politics of representation. In S. Chalkin \& J. Lave (Eds.), Understanding practice: Perspectives on activity and context (pp. 241-268). New York: Cambridge University Press.

Meiners, E. R. (2017). The problem child: Provocations toward dismantling the carceral state. Harvard Educational Review, 87(1), 122-146. doi:10.17763/1943-5045-87.1.122

Morris, E. W. (2005a). “Tuck in that shirt!” Race, class, gender, and discipline in an urban school. Sociological Perspectives, 48(1), 25-48. doi:10.1525/sop.2005.48.1.25

Morris, E. W. (2005b). From “middle class" to "trailer trash": Teachers' perceptions of white 
students in a predominately minority school. Sociology of Education, 78(2), 99. doi:10.1177/003804070507800201

Morris, M. (2016). Pushout: The criminalization of Black girls in school. New York: New Press.

Musto, M. (2019). Brilliant or bad: The gendered social construction of exceptionalism in early adolescence. American Sociological Review, 84(3), 369-393. doi: $10.1177 / 0003122419837567$

Nasir, N. S., Snyder, C. R., Shah, N., \& Ross, K. M. (2013). Racial storylines and implications for learning. Human Development, 55(5-6), 285-301. doi:10.1159/000345318

Nelson, J. D. (2020). Relationships of (re)imagining: Black boyhood, the race-gender discipline gap, and early-childhood teacher education. The New Educator 16 (2), 122-130. doi:10.1080/1547688X.2020.1739932

Noguera, P. A. (2008). The trouble with Black boys, and other reflections on race, equity, and the future of public education. San Francisco: Jossey-Bass.

Owens, J., \& McLanahan, S. S. (2019). Unpacking the drivers of racial disparities in school suspension and expulsion. Social Forces 98 (4), 1548-1577. doi:10.1093/sf/soz095

Posey-Maddox, L. (2014). When middle-class parents choose urban schools: Class, race, and the challenges of equity in public education. Chicago: University of Chicago Press.

Quarles, B., \& Butler, A. (2018). Toward a multivocal research agenda on school gentrification: A critical review of current literature. Peabody Journal of Education, 93(4), 1-15. doi:10.1080/0161956X.2018.1488399

Ramey, D. M. (2015). The social structure of criminalized and medicalized school discipline. Sociology of Education, 88(3), 181-201. doi:10.1177/0038040715587114 Shalaby, C. (2017). Troublemakers: Lessons in freedom from young children in school. New 
York: New Press.

Skiba, R. J., Arredondo, M. I., \& Rausch, M. K. (2014). New and developing research on disparities in discipline. The Equity Project at Indiana University. Retrieved from http://www.indiana.edu/ atlantic/wpcontent/uploads/2014/03/Disparity_NewResearch_Full_031214.pdf

Skiba, R. J., Michael, R. S., Carroll Nardo, A., \& Peterson, R. (2000). The color of discipline. The Urban Review 34, 317-342.

Thorne, B. (1993). Gender play: Girls and boys in school. New Brunswick, NJ: Rutgers University Press.

US Department of Education, Office for Civil Rights. (2014). Data snapshot: School discipline. In Civil Rights Data Collection (Vol. 1, Issue 1). Retrieved from http://search.ebscohost.com/login.aspx?direct=true\&db=eric\&AN=ED577231\&site=ehostlive

Valenzuela, A. (1999). Subtractive schooling: U.S.-Mexican youth and the politics of caring. Albany: State University of New York Press.

Walkerdine, V. (1998). Developmental psychology and the child-centered pedagogy: The insertion of Piaget into early education. In J. Henriques, W. Hollway, C. Urwin, C. Venn, \& V. Walkerdine (Eds.), Changing the subject: Psychology, social regulation and subjectivity (pp. 167-196). New York: Routledge.

Walkerdine, V. (1999). Violent boys and precocious girls: Regulating childhood at the end of the millennium. Contemporary Issues in Early Childhood, 1(1), 3-23. doi:10.2304/ciec.2000.1.1.5

Watts, I. E., \& Erevelles, N. (2004). These deadly times: Reconceptualizing school violence by 
using critical race theory and disability studies. American Educational Research Journal, 41(2), 271-299. doi:10.3102/00028312041002271

Wortham, S. (2006). Learning identity: The joint emergence of social identification and academic learning. New York: Cambridge University Press.

Wortham, S. (2008). The objectification of identity across events. Linguistics and Education, 19(3), 294-311. doi:10.1016/j.linged.2008.05.010

Wright, A., Gottfried, M. A., \& Le, V.-N. (2017). A kindergarten teacher like me: The role of student-teacher race in social-emotional development. American Educational Research Journal, 54(1S), 78S-101S. doi:10.3102/0002831216635733

Zimmermann, C. R. (2018). The penalty of being a young Black girl: Kindergarten teachers' perceptions of children's problem behaviors and student-teacher conflict by the intersection of race and gender. Journal of Negro Education, 87(2), 154-168. doi:10.7709/jnegroeducation.87.2.0154

\section{Acknowledgments}

I owe huge thanks to Joseph Nelson for showing me that this paper was about Hazel, not Marquise, and for providing invaluable feedback on how to most effectively frame her story. I am grateful to Ariana Mangual Figueroa, Kathryn Boonstra, Maisha Winn, Jill Pierce, and members of the Harvard Educational Review Editorial Board for feedback on earlier versions of this manuscript. This project would not have been possible without support and partial funding from the National Academy of Education/Spencer Dissertation Fellowship, the Fahs-Beck Fund for Research and Experimentation at The New York Community Trust, and the Mitchell Leaska Dissertation Research Award. 
